\title{
THE ROYAL SOCIETY OF
}

\section{E D I N B UR G H}

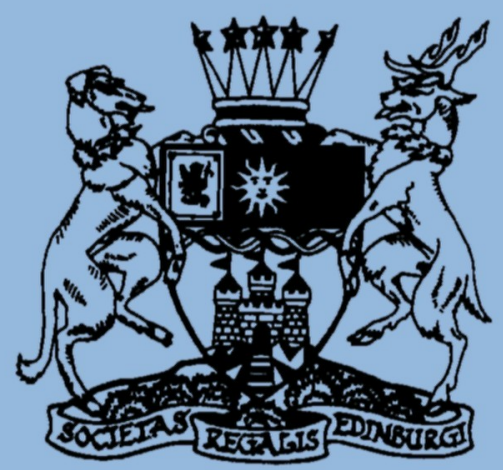

PROCEEDINGS SECTION A M A T H E M A T I C S

PUBLISHED BY THE ROYAL SOCIETY OF EDINBURGH 22 GEORGE STREET, EDINBURGH EH 22 PQ 


\section{EDITORIAL BOARD}

\section{Executive Editors}

J. CARR

Heriot-Watt University

A. M. DAVIE

University of Edinburgh
T. J. LYONS

Imperial College, London

\section{J. C. EILBECK}

Heriot-Watt University

W. N. EveritT

University of Birmingham

J. R. HubBUCK

University of Aberdeen

A. J. R. G. MILNER

University of Edinburgh

A. A. RaNICKI

University of Edinburgh

\section{B. StRAughaN}

University of Glasgow

A. Truman

University College, Swansea
F. WILLETT

Curator

Glasgow

\section{Consulting Editors}

H. BREZIS

Université de Paris VI

C. M. DAFERMos

Brown University,

Providence, RI, USA

S. K. Donaldson

University of Oxford

R. G. Douglas

State University of New York at

Stony Brook, USA

L. E. FraenKeL

University of Bath

M. GiaquinTA

Università degli

Studi di Firenze

J. K. Hale

Georgia Institute of Technology,

USA

K. KIRCHGASSNER

Universität Stuttgart

ROBERT V. KOHN

New York University

P. L. Lions

Université de Paris IX

H. Matano

University of Tokyo,

Japan

M. Mimura

Okayama University,

Japan
O. A. Oleinik

Moscow State University,

USSR

A. Yu. OlshanskiI

Moscow State University,

Russia

D. S. PASSMAN

University of Wisconsin-

Madison

J. M. SANZ-SERNA

Universidad de Valladolid, Spain

W. G. Strang

Massachusetts Institute of

Technology, Cambridge, USA

C. A. STUART

École Polytechnique Fédérale

de Lausanne

L. TARTAR

Carnegie-Mellon University,

Pittsburgh, USA

J. TOLAND

University of Bath

N. S. TRUDINGER

Australian National University,

Canberra, Australia

G. Q. ZHANG

Peking University, Beijing

W. A. ZHENG

University of California, Irvine, USA

Publications Manager, Royal Society of Edinburgh: T. G. Dart

The Royal Society of Edinburgh Proceedings Section A Mathematics is published every two months by the Royal Society of Edinburgh. Subscription price is $£ 192.00$ for six issues (vol. 124). Orders, claims etc. should be addressed to CAB International, Wallingford, Oxon OX10 8DE, U.K. (Tel: (0491) 832111; Fax (0491) 826090)

Second Class postage pending at Jamaica, N.Y., Postmaster send address corrections to The Royal Society of Edinburgh Proceedings Section A Mathematics, c/o IMD, 14905 177th St, Jamaica, N.Y. 11434, U.S.A. 